DOI: $10.30519 /$ ahtr.784232

\begin{tabular}{lr} 
Advances in Hospitality and Tourism Research (AHTR) & 2021 \\
An International Journal of Akdeniz University Tourism Faculty & Vol. 9 (1) \\
ISSN: 2147-9100 (Print), 2148-7316 (Online) & $132-156$ \\
Webpage: http://www.ahtrjournal.org/ & \\
\hline
\end{tabular}

\title{
HOW DELIGHTFUL IS INDIAN WELLNESS TOURISM? A NETNOGRAPHIC STUDY
}

\author{
Dibya Nandan MISHRA ${ }^{1}$ \\ School of Management, National Institute of Technology Rourkela, India \\ ORCID: 0000-0002-9918-115X \\ Rajeev Kumar PANDA \\ School of Management, National Institute of Technology Rourkela, India \\ ORCID: 0000-0003-1351-7167
}

\begin{abstract}
The growing number of wellness care facilities in India has raised concern over the service quality that is being provided to the tourists. This research targets to explore the dimensions of wellness tourism service quality based on customers' quality perception. Social media platforms such as Google reviews and hotel review blogs/websites were used to gather 400 public reviews. A Naïve Bayes machine learning Sentiment Analysis approach was used to identify critical areas to improve service delivery, customer relationship, and hospitality management in wellness resorts. Tangibility was identified as the most important dimension followed by empathy, assurance, reliability, and responsiveness. Assurance, empathy, and reliability have the most negative sentiments shared by tourists. Food quality, rooms and accommodation facilities, safety and security, attitude towards customer complaints, the behaviour of the staff, error-free services, and proper training are areas upon which Indian wellness resorts should focus. This study intends to identify additional constructs in future research and build robust models to actively rank the important factors for better customer engagement. Research findings may support managers and policymakers to identify areas of improvement to help them develop the wellness resorts in India.
\end{abstract}

\author{
Article History \\ Received 23 August 2020 \\ Revised 30 January 2021 \\ Accepted 1 February 2021 \\ Keywords \\ wellness resorts \\ wellness tourism \\ sentiment analysis \\ service quality \\ customer experience \\ machine learning
}

Available online 8 March 2021

\footnotetext{
${ }^{1}$ Address correspondence to Dibya Nandan MISHRA, School of Management, National Institute of Technology Rourkela, Rourkela, Odisha, INDIA. E-mail: dibyanandanmishra@gmail.com
} 


\section{INTRODUCTION}

The growth in world travel and tourism creates ample opportunities for both developed and developing countries. International tourists help in creating opportunity for development of employment opportunities, foreign exchange earnings, and tourism investment (Csirmaz \& Pető, 2015; Neto, 2003). In the last few years, tourism saw a dynamic development in the area of wellness tourism at both national and international levels. Experts say that it is one of the fastest-growing areas of tourism and is forecasted to expand further. A worldwide total of 586 million wellness trips is taken each year, which accounts $15 \%$ of the total global travel (Karai, 2019). "Wellness tourism" as a term is often used to describe tourism activities which helps to develop the wellness, body and mind health, and quality of life of an individual (Hall et al., 2011). Wellness tourism is sometimes confused with medical tourism. While medical tourism is travel to treat an illness, wellness tourism is more about improving the wellbeing of the body and mind (Global Wellness Institute, 2017). Our body needs to get away from stress and the weariness of long and monotonous hours of work. Wellness holidays are a great way to gift our body with happiness and rejuvenation. Wellness tourism is for the people who need a break from their regular work for the development of their physical and mental health.

The world's global wellness economy stands at USD 4.5 trillion as of 2019 (Global Wellness Institute, 2019). Of which, wellness tourism is at USD 639 billion. The sector is expected to grow at a CAGR of $7.5 \%(2017-2022)$ to reach USD 919 billion by 2022 (Global Wellness Institute, 2018). Further, the report states that China and India will take one third of the total growth of the Asia-pacific region alone. India has prospered from capturing a strong tourist base in the name of a wellness retreat. In 2019, India was ranked $23^{\text {rd }}$ in the world with 10.93 million foreign tourist arrivals (annual growth of $3.5 \%$ ). Of the total arrivals, $6.4 \%$ were for medical tourism which includes wellness as a part of it. The medical tourism sector grew by $6.1 \%$ from the previous year (Ministry of Tourism, 2019, 2020). India has an edge over its competitors when it comes to wellness-based tourism, with untapped potential and an abundance of natural resources. Its rich culture and indigenous medicines and therapies such as Ayurveda, Yoga, Unani, Sidha, Homeopathy, and Naturopathy make India a haven for wellness tourism. Though India has been efficacious in medical tourism; it is still low when compared to the total share of the total global wellness tourism market. Strategic efforts need to be made for position India on a global stage (Bhowmick, 2018). 
Wellness tourism brings many economic benefits, with it arises challenges in providing quality of service and combat to retain the customer. Wellness service providers are fast increasing in India. Ministry of AYUSH has shown concern about the service quality provided by these companies. AYUSH extends to Ayurveda, Yoga, and Naturopathy, Unani, Siddha, and Homoeopathy. Established in 2014, the main vision of this ministry is to develop and educate the public about the indigenous alternative medicine system in India. The ministry focuses on developing the quality of the wellness delivery centres to attract more tourists both from India and abroad. With increasing demand and the untapped potential of wellness tourism, the ministry needs to focus on service quality to retain tourists. Owing to this fact, service quality has been considered as the most crucial factor to form a long-term relationship between customer and service provider (Arasli et al., 2005; Cronin \& Taylor, 1992). This study explores the different dimensions by which wellness providers may improve the service experiences of tourists.

This paper investigates the delivery of services by wellness resorts to their customers through social media reviews. Social media has become an essential part of communication. Platforms such as Facebook, Twitter, Instagram, blogs, and other websites do not only help to reach customers but also provide benefits in understanding customer requirements. Increases in the use of social media bring both opportunities and threats for organisations. Increasing customer engagement with the service provider in the virtual world creates an opportunity to better understand customer needs based on their feedback. Social media brings in more transparency in the customer-service provider relationship and displays customer feedback in an open world. The never-ending content created in social media (termed as user-generated content (UGC)) helps in understanding and representing information in a meaningful way to help an organisation win against its competitors (Blackshaw, 2005).

Based on the need to understand customer perceptions of service quality in Indian wellness resorts and the possible effects of service quality practices on customer satisfaction, the study aims to; (1) gain customer insights on the wellness care services provided by the resorts in India through social media reviews; (2) identify the crucial factors which may help to enhance the customer service experience in Indian wellness resorts; (3) understand customer sentiment on the service quality of Indian wellness resorts through sentiment analysis; and (4) develop and implement machine learning algorithms to predict and interpret future customer service encounters and concerns. 
The study attempts to identify the critical quality dimensions essential to elevate service performance by analysing customer reviews and opinions shared on tourism platforms, such as Google reviews. Machine learning-based sentiment analysis is used to understand customer opinions about their service experiences and classify text into identified quality dimensions. The majority of the research is survey-based, which takes into account tourist reviews for a particular period of time; and the potential of wellness care as a part of recreational tourism has not been deeply researched. In our research, we have incorporated the social media reviews of the selected resorts. The time frame of the selected reviews is from the day of the first review till December 2019. This research also showcases an alternative to traditional survey-based data collection. Social media input and supervised/unsupervised netnography techniques make the study faster and more cost-effective.

\section{LITERATURE REVIEW}

\section{Wellness Tourism}

The increasing pace of life, uneven work-life balance, loss of traditional and religious organisation and desire for relaxation and finding a meaning to life are a few of the reasons that have given rise to the wellness industry in the world (Douglas, 2001; Pollock \& Williams, 2000; Smith \& Puczko, 2008). Demand for a more holistic approach to living a healthy life and the escalating cost of western medicine has helped to increase the demand for wellness care and therapies (Sointu, 2006; Weiermair \& Steinhauser, 2003). Wellness tourism accompanies age tourism, volunteer tourism, sports and adventure, yoga and spiritual tourism, and religious tourism (Ali-Knight, 2009; Hall, 1992; Kulczycki \& Luck, 2009; Lean, 2009; Smith \& Kelly, 2006).

\section{Dimensions of Service Quality in the Hospitality and Tourism Industry}

A firm may create a competitive advantage through the quality and value of products and services it is able to provide (Hutchinson et al., 2009; Zeithaml et al., 1996). Since the 1980s, service quality has been differently defined and discussed by many authors (Singh \& Khanduja, 2010). Service quality is a group of intangible activities between customers and service employees (Shahin \& Chan, 2006). While Santos (2003) defined service quality as a measure of satisfaction of customer experiences, Muturi et al. (2013) observed that the definition of service quality depends on the context of the study and its focus on meeting customer expectations. While 
products can be measured and quantified, services are quite difficult to measure because of their intangible nature. Service performance is highly varied and is dependent on the service person who is in direct contact with the customer (Juwaheer, 2004). When it comes to services such as wellness treatments, products and services are inseparable and involve a high amount of customer participation. Customers measure quality in terms of the positive difference between the expectation and the actual delivery of the service. The sole aim of the service provider is to meet or go beyond the expectations of its customers (Parasuraman et al., 1985). Previous studies are discussed in this context to identify the important dimensions in the hospitality and tourism sector.

Sharma (2014) measured customer satisfaction in Indian hotels and concluded that tangibles and responsiveness were the crucial factors followed by reliability, assurance, and empathy. A study in top hotels in Tirana revealed empathy and tangibility as the most crucial dimensions followed by assurance, responsiveness, and reliability (Godolja \& Spaho, 2014). Tangibility creates the first impression as it is visible in the first instance. Basic cleanliness and tidiness are expected by every customer; researchers argue that a lack of cleanliness is a prime reason which diverts travellers from a hotel, while exceptional cleanliness does not attract them (Lewis \& Nightingale, 1991). The service encounter between the customer and the employee is a significant determinant affecting customer perceptions of service quality. Helpfulness of staff, error-free service, understandability, friendliness, and polite attitude are essential in determining service quality (Oberoi \& Hales, 1990). Choi and Chu (2001) identified staff behaviour, service delivery, quality of accommodation, and overall value to be the most critical factors influencing customer satisfaction and retention. In a study on the wellness centres in Croatia, the 'appearance of facilities and employees' was concluded to be an essential factor in improving the service quality in the wellness tourism industry (Markovic et al., 2012). The authors also concluded that empathy and assurance are deciding factors for gaining customer loyalty. Safety and security systems are also identified as a potent tool for a hotel to gain traveller confidence and trust (Marshall, 1993). A good number of studies have proven the importance of service quality and its impact on creating a customer relationship. Much of the research is survey-based. This study is one of the few to take social media as a tool and implement machine learning and text analytics to gain customer insights and to understand the dimensions of service quality which impact the relationship between customers and service providers. 


\section{METHODOLOGY}

The study investigates online customer opinions shared on online review platforms. Here customer reviews of Indian wellness resorts are taken from online social media platforms such as Google map reviews, hotel booking sites, hotel websites, and expert blogs. The reviews will help us to identify essential elements in customer experience in selected Indian wellness resorts. The opinion mining (sentiment analysis) technique was incorporated to understand consumer behaviour and the importance of such methods in the field of management. Google reviews, hotels.com, and similar travel and tourism websites were used to collect customer opinions. Eight Indian resorts/hotels providing wellness facilities to their customers were identified (Rai, 2018). The resorts selected were Ananda in the Himalayas, Uttrakhand; Isha Yoga Centre, Tamil Nadu; Vana Retreat, Uttrakhand; Souled and Surf, Kerela; SwaSwara, Karnataka; Somatheeram Ayurveda Resort, Kerala; Yab Yum Resort, Goa; and Spa Alila, Goa. The resorts provide wellness services such as Ayurveda, yoga, and traditional massages. They also deal with organic food and indigenous therapy treatments. 400 customer reviews were mined from different blogs and websites for the above-mentioned wellness resorts (all reviews till December 2019). Hindi or Indian regional language reviews were ignored to avoid translational complexities (Thelwall et al., 2011). A customer shares an array of comments relating to each quality dimension identified in our literature. To better analyse and interpret customer intentions, individual sentences were extracted by fragmenting each review. Reviews were fragmented into 4,984 individual sentences each portraying a different dimension.

Manual classification of each sentence was done by connecting it to the attributes identified from the literature. The identified dimensions are part of the SERVQUAL model defined by Parasuraman et al. (1988). This paper explores the research in the area of hospitality and tourism to understand different types of questions asked to respondents in order to measure the different quality dimensions. Annex A (see Appendix) shows the quality dimensions and the attributes derived from various literature (Bhat, 2012; Parasuraman et al., 1991; Ramsaran-Fowdar, 2007). These attributes were taken into consideration to manually classify the reviews according to each dimension shared by consumers. 


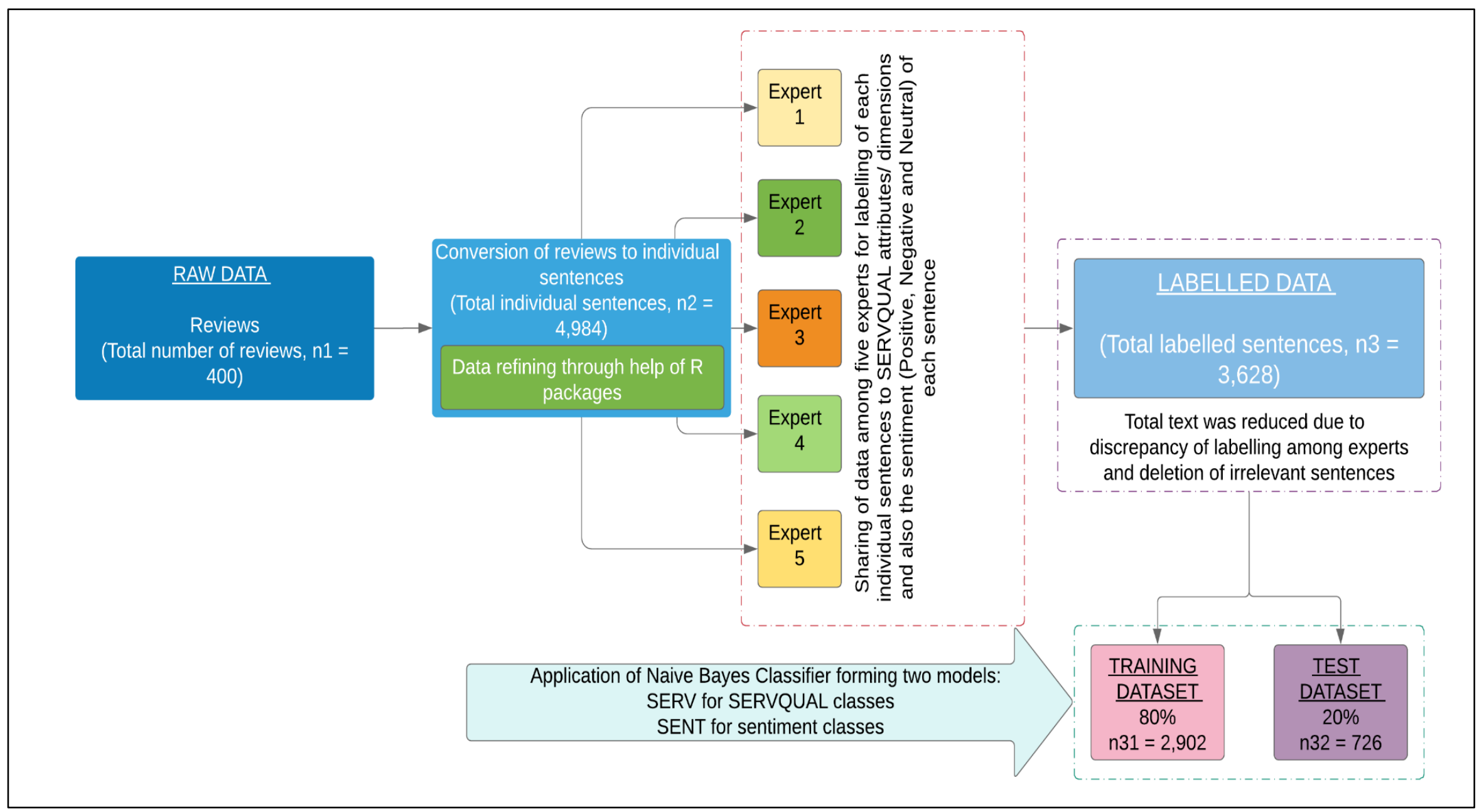

Figure 1. Flowchart describing the process of data collection to data processing and result 
Five individuals with sound knowledge on the topic of service quality were asked to label each sentence into different dimensions. The labelling was matched for all five responses and was reverified by the authors for any mismatch between the labels. Only 7\% of the total dataset had a mismatch which was then relabelled by the authors. Simultaneously, the sentences were also classified into negative, positive, and neutral categories by understating their sentiment. The same verification process was done to check dissimilarities among the labels (9\% of the dataset had a mismatch). After classifying all the sentences, only 3,628 sentences were found to be relevant to our study. Annex A shows the quality dimensions and the attributes which were derived from various literature and were taken into consideration to manually classify actual customer reviews shared on social media. Figure 1 portrays a flowchart of the process used to analyse the raw data to result.

Two Naïve Bayes classifier models were formed to classify the sentences into the identified quality dimensions, and the sentiment (positive, negative, and neutral) with this mentioned as SERV and SENT models, respectively. Eighty percent of the data (2,902 comments) was taken to train the model, and the remaining $20 \%$ was used (726) to test the accuracy of the model/ algorithm. R Studio platform was used to programme the algorithm for the Naïve Bayes classifier to conduct sentiment analysis.

\section{Sentiment Analysis of Social Media Reviews}

Social media was introduced to develop online networking capabilities but soon became the most sought-after medium for customers to share their product and service experiences (Kho, 2010; Misopoulos et al., 2014). Social media comprises online social communities such as Facebook, LinkedIn, Myspace, and Twitter; blogs; content communities such as Flickr and YouTube; online encyclopaedias such as Wikipedia; social bookmarking; and news sites such as Delicious, Digg, and Reddit (Boyd \& Ellison, 2007; Constantinides \& Fountain, 2008). Studies have shown that consumers are more active on social media in voicing their concerns and experiences with a service or product (Geho et al., 2010; Wei et al., 2008). The growing volume of information on social media has created an opportunity to plough meaningful insight towards consumer perceptions of the service being used (O'Leary, 2011). This study uses sentiment analysis which has shown effectiveness and efficiency in analysing unstructured online content across online platforms such as Twitter, Facebook, TripAdvisor, YouTube, and other prevailing social media platforms (Arnold, 2011; Ku et al., 2009). 
According to Deshpande and Sarkar (2010) sentiment analysis helps to process unstructured content into structured information, bringing out critical customer insights in the form of patterns, trends, and events. The hospitality and service industries are brilliant examples of how social media data is used to gain customer insights and experiences (Gretzel \& Yoo, 2008). Sentiment analysis is applied in many industries related to hospitality, such as telecommunications, hotels, airlines, and retail stores (Rambocas \& Pacheo, 2018). A large number of travellers get involved in social media platforms to provide feedback and recommendations to other travellers and using information from social media has become more crucial (Yang et al., 2018; Ye et al., 2009). Alaei et al. (2019) reviewed various empirical studies which used a lexicon or machine learning-based sentiment analysis approach in the tourism industry. The experts portrayed the importance of a sentiment analysis-based approach as an essential tool for future research in understanding customer experiences. For instance, Philander and Zhong (2016) implemented the dictionary-based (lexicon) method to analyse Twitter data from well-known resorts in Las Vegas. The use of social media helps to gather data from customer's electronic Word of Mouth (eWOM) behaviours. Social media as a tool empowers customers to be more self-expressive; the use of analytical tools, such as sentiment analysis, may help to effectively and rapidly understand customers. Taking advantage of these factors, Xiang et al. (2015) used text mining to identify critical elements associated with customer satisfaction. Sentiment analysis and opinion mining have proved superior in comparison to the traditional survey-based approach which is both time-consuming and costly (Koppel \& Schler, 2006).

\section{RESEARCH FINDINGS}

\section{Implementation of SERV model}

About $45 \%$ of the reviews were about tangible aspects and the rest were about other dimensions of service quality. Due to uneven class distribution, it is better to use the F1 score rather than just the accuracy (Joshi, 2016). The F1 score of the model is $78.9 \%$, while the overall accuracy of the SERV model was found to be $85.26 \%$. Laplace smoothing was used to avoid zero probability estimates (Peng \& Schuurmans, 2003). The accuracy is more than the no information rate which validates the usefulness of the model. No information rate relates to the largest class percent of data present in the complete dataset. The model shows a good agreement among the classes with Cohen's kappa value of 0.80 (Cohen, 1960). Both the P-value and 
Mcnemar's Test P-value have a value less than 0.05 (Confidence Interval of 95\%); thus, the model formed is significant. All the formulas used to calculate the confusion matrix are described in Annex B (see appendix).

Table 1. Nä̈ve Bayes classifier truth table for SERV model

\begin{tabular}{|c|c|c|c|c|c|c|c|c|}
\hline \multicolumn{9}{|c|}{ Actual Result } \\
\hline & & 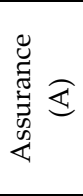 & 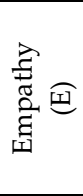 & 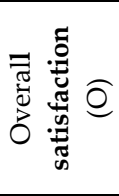 & 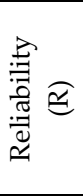 & 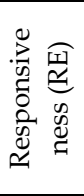 & 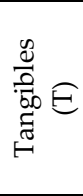 & 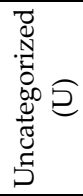 \\
\hline \multirow{8}{*}{ 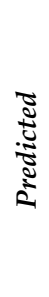 } & Assurance & 91 & 2 & 1 & 1 & 0 & 1 & 0 \\
\hline & Empathy & 3 & 75 & 4 & 0 & 0 & 1 & 0 \\
\hline & Overall satisfaction & 1 & 1 & 95 & 1 & 0 & 13 & 1 \\
\hline & Reliability & 2 & 1 & 6 & 36 & 2 & 1 & 0 \\
\hline & Responsiveness & 4 & 0 & 7 & 5 & 21 & 2 & 0 \\
\hline & Tangibles & 2 & 1 & 12 & 2 & 1 & 293 & 0 \\
\hline & Uncategorized & 1 & 0 & 8 & 1 & 0 & 19 & 8 \\
\hline & Total & 104 & 80 & 133 & 46 & 24 & 330 & 9 \\
\hline
\end{tabular}

Table 2. Naïve Bayes classifier Performance/Confusion Matrix for SERV model

\begin{tabular}{|c|c|c|c|c|c|c|c|}
\hline \multicolumn{8}{|l|}{ Overall Statistics } \\
\hline F1 Score & \multicolumn{7}{|c|}{$78.90 \%$} \\
\hline Accuracy & \multicolumn{7}{|c|}{$85.26 \%$} \\
\hline No Information Rate (NIR) & \multicolumn{7}{|c|}{$45.45 \%$ (Largest Class: Tangibles) } \\
\hline P-Value (Acc > NIR) & \multicolumn{7}{|c|}{$<2.2 \mathrm{e}-16$} \\
\hline Kappa & \multicolumn{7}{|c|}{0.8005} \\
\hline Mcnemar's Test P-Value & \multicolumn{7}{|c|}{$<2.2 \mathrm{e}-16$} \\
\hline \multicolumn{8}{|l|}{ Statistics by Class } \\
\hline & $A$ & $E$ & $O$ & $R$ & $R E$ & $T$ & $u$ \\
\hline Sensitivity & $87.50 \%$ & $93.75 \%$ & $71.43 \%$ & $78.26 \%$ & $87.50 \%$ & $88.79 \%$ & $88.89 \%$ \\
\hline Specificity & $99.20 \%$ & $98.76 \%$ & $97.13 \%$ & $98.24 \%$ & $97.44 \%$ & $95.45 \%$ & $95.96 \%$ \\
\hline Prevalence & $14.33 \%$ & $11.02 \%$ & $18.32 \%$ & $6.34 \%$ & $3.31 \%$ & $45.45 \%$ & $1.24 \%$ \\
\hline 1 - Prevalence & $85.67 \%$ & $88.98 \%$ & $81.68 \%$ & $93.66 \%$ & $96.69 \%$ & $54.55 \%$ & $98.76 \%$ \\
\hline $\begin{array}{l}\text { Positive Predicted Value } \\
\text { (Precision) }\end{array}$ & $94.79 \%$ & $90.36 \%$ & $84.82 \%$ & $75.00 \%$ & $53.85 \%$ & $94.21 \%$ & $21.62 \%$ \\
\hline Negatively Predicted Value & $97.94 \%$ & $99.22 \%$ & $93.81 \%$ & $98.53 \%$ & $99.56 \%$ & $91.08 \%$ & $99.85 \%$ \\
\hline
\end{tabular}

Table 1 and Table 2 depict the truth table and the overall performance (Confusion Matrix) of the SERV model. Sensitivity in the confusion matrix defines the actual number of correctly identified real positives. Specificity measures the correctly identified actual negatives. The higher the percentage of sensitivity/specificity, the better is the identification (better accuracy of the model). Positive Predicted Value (Precision value, PPV) is higher than the corresponding prevalence value; this states that our model may add useful information while predicting the result. Prevalence talks about what proportion of data in our model is relevant. Prevalence shows the real positives in the dataset. Similarly, the 
Negative Predicted Value (NPV) is also higher than 1- Prevalence. Higher PPV and NPV values create a chance of the instance being present within the subset of the entire dataset.

\section{Implementation of SENT model}

Table 3 and Table 4 depict the truth table and the overall performance of the SENT model. The F1 score of the model is $86.3 \%$. The overall accuracy of the SERV model was found to be $89.53 \%$. The model shows a good agreement among the classes with Cohen's kappa value of 0.80 . Both the Pvalue and Mcnemar's Test P-value have a value less than 0.05 (Confidence Interval of 95\%); thus, the model formed is significant. The PPV is higher than the corresponding prevalence value; this states that our model may add useful information while predicting the result. Similarly, NPV is also higher than 1 - Prevalence. The need for our research is to find negative reviews and help managers to take action to solve those issues. Therefore, our model must have better accuracy in Specificity and NPV; our model has a good accuracy rate of more than $90 \%$ for the specificity and NPV in almost all of the classes.

Table 3. Nä̈ve Bayes classifier truth table for SENT model

\begin{tabular}{|c|c|c|c|c|}
\hline & & \multicolumn{3}{|c|}{ Actual Result } \\
\hline \multirow{5}{*}{ 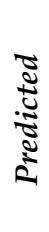 } & & Negative & Neutral & Positive \\
\hline & Negative & 238 & 12 & 32 \\
\hline & Neutral & 4 & 56 & 12 \\
\hline & Positive & 11 & 5 & 356 \\
\hline & Total & 253 & 73 & 400 \\
\hline
\end{tabular}

Table 4. Naïve Bayes classifier Performance/Confusion Matrix for SENT model

\begin{tabular}{|c|c|c|c|}
\hline \multicolumn{4}{|l|}{ Overall Statistics } \\
\hline F1 Score & & \multicolumn{2}{|l|}{$86.30 \%$} \\
\hline Accuracy & & \multicolumn{2}{|l|}{$89.53 \%$} \\
\hline No Information Rate (NIR) & & \multicolumn{2}{|c|}{$55.10 \%$ (Largest Class: Positive) } \\
\hline P-Value (Acc > NIR) & & \multicolumn{2}{|l|}{$<2.2 \mathrm{e}-16$} \\
\hline Kappa & & \multicolumn{2}{|l|}{0.8171} \\
\hline Mcnemar's Test P-Value & & \multicolumn{2}{|l|}{$<2.2 \mathrm{e}-16$} \\
\hline \multicolumn{4}{|l|}{ Statistics by Class } \\
\hline & Negative & Neutral & Positive \\
\hline Sensitivity & $94.07 \%$ & $76.71 \%$ & $89.00 \%$ \\
\hline Specificity & $90.70 \%$ & $97.55 \%$ & $95.09 \%$ \\
\hline Prevalence & $34.85 \%$ & $10.06 \%$ & $55.10 \%$ \\
\hline 1 - Prevalence & $65.15 \%$ & $89.94 \%$ & $44.90 \%$ \\
\hline $\begin{array}{l}\text { Positive Predicted Value } \\
\text { (Precision) }\end{array}$ & $84.40 \%$ & $77.78 \%$ & $95.70 \%$ \\
\hline Negatively Predicted Value & $96.62 \%$ & $97.40 \%$ & $87.57 \%$ \\
\hline
\end{tabular}


Table 5 illustrates the total number of comments in each dimension and the sentiment shared by customers across each dimension while Figure 2 shows the sentiments shared by the customer about the selected wellness resorts. It is visually apparent that most of the sentiments shared were positive. However, the primary objective is to understand the areas which have more negative comments; this may help the resorts to improve their overall service and hospitality towards their customers.

Table 5. Total comments under each dimension and their sentiment

\begin{tabular}{llccccc}
\hline Dimensions & $\begin{array}{c}\text { Total } \\
\text { Comments }\end{array}$ & $\begin{array}{c}\text { Positive } \\
(\boldsymbol{P})\end{array}$ & Neutral (Ne) & $\begin{array}{c}\text { Negative } \\
(\mathbf{N})\end{array}$ & $\begin{array}{c}\text { Ratio } \\
(\mathbf{P}: \text { Ne: } \boldsymbol{N})\end{array}$ \\
\hline 1 & Assurance & 544 & 288 & 11 & 245 & $53: 02: 45$ \\
2 & Empathy & 472 & 184 & 38 & 250 & $39: 08: 53$ \\
3 & Overall & 399 & 311 & 20 & 68 & $78: 05: 17$ \\
& satisfaction & & 222 & 4 & 209 & $51: 01: 48$ \\
4 & Reliability & 435 & 228 & 15 & 120 & $63: 04: 33$ \\
5 & Responsiveness & 363 & 896 & 69 & 413 & $65: 05: 30$ \\
6 & Tangibles & 1378 & 30 & 4 & 3 & $81: 11: 08$ \\
7 & Uncategorized & 37 & $\mathbf{2 1 5 9}$ & $\mathbf{1 6 1}$ & $\mathbf{1 3 0 8}$ & $\mathbf{6 0 : 0 4 : 3 6}$ \\
\hline
\end{tabular}

Note: The result includes predicted result and not the manually coded result for the $20 \%$ of the test comments.

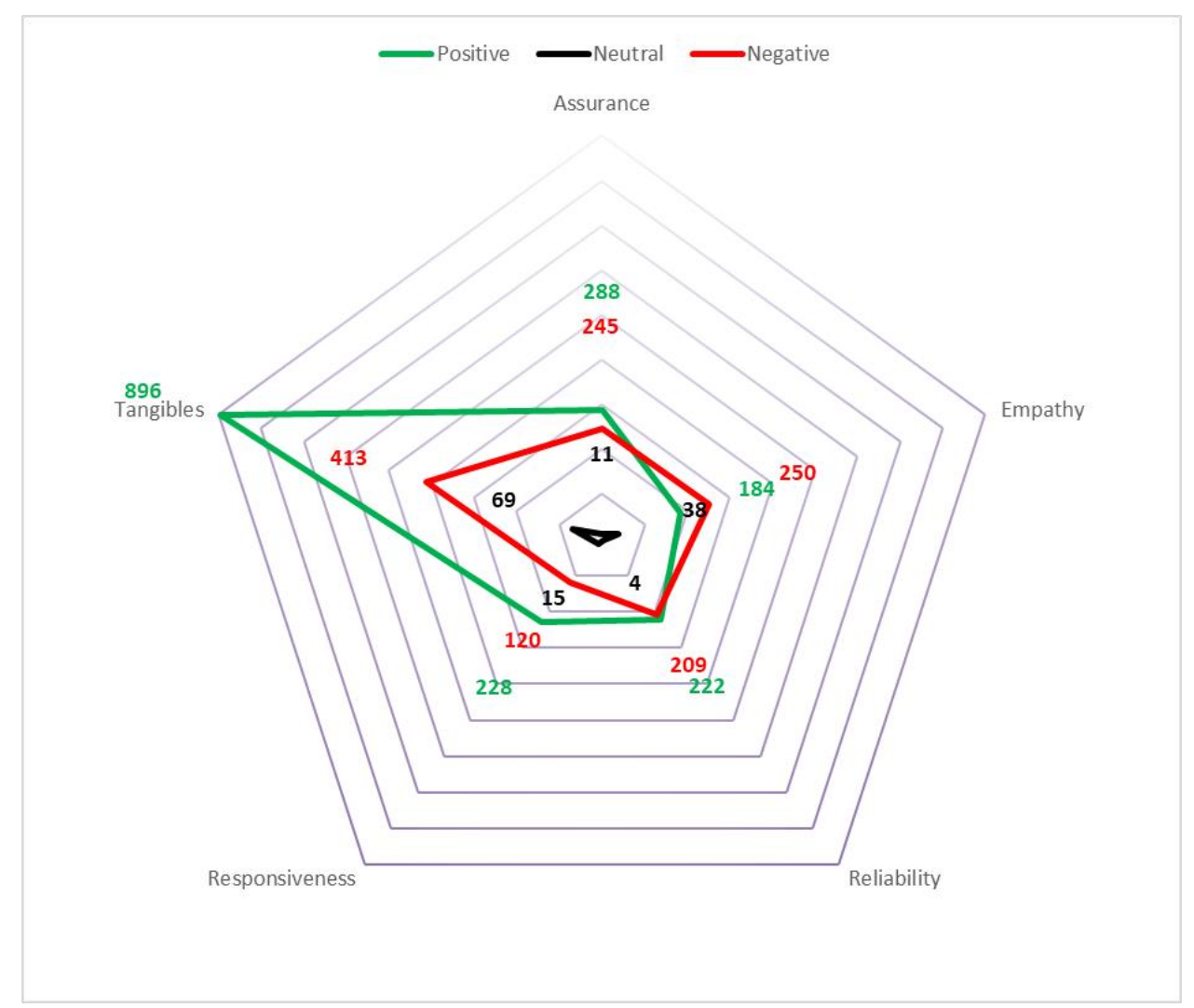

Figure 2. Sentiment shared across SERVQUAL dimensions

Note: The overall satisfaction and uncategorised category have not been shown in the graph as they are not part of the SERVQUAL model. 
As derived from the results, customers shared more views on Tangibles as compared to other dimensions. Customers have more preferences towards the aesthetics and facilities provided by the resorts as compared to the services delivered by staff. Almost $65 \%$ of the comments shared a positive sentiment for the facilities provided by the selected wellness care. On the other hand, negative sentiments were comprised of food quality, lousy Internet connections, and unsatisfactory aesthetics and living conditions, as illustrated by the following comments:

"While the place looks charming at first and the people who work here are very kind, the dome rooms smell, leak when it rains, and we learned on our last night here have rats living in the walls of the thatched domes."

"We came back from dinner and the cottage smells so heavily of cigarette smoke that I'm not sure my kids can actually sleep here."

Empathy is the most negatively perceived factor. Empathy talks about the individual care and personal attention to the customer; for instance, calling the customer by name, room service, listening to complaints, and meeting any customised needs. Fifty-three percent of the comments categorised under Empathy had a negative sentiment. The majority of the negative comments came from the attitude towards unsolved complaints raised by customers. Resorts should investigate to increase their service quality in the area of empathy. Some examples of negative sentiments shared by customers are:

"On realising the error they blamed me and said I'd have to pay a very large cancellation fee."

"However, having reported this directly with the owners with no response it leaves a bitter taste in the mouth."

The Assurance and Reliability categories had a mixed review of an almost equal number of positive and negative sentiments. Customers in a few of the selected hotels were not satisfied with the behaviour of the staff, lack of friendliness, unwelcoming behaviour, errors in services, and lack of proper training. A few of the negative sentiments shared are:

"although everything was done efficiently at reception, like check in/out and organising taxis, I felt that the staff were not welcoming or friendly."

"We never felt welcomed when we checked in and throughout our stay, this was consistent with the staff (apart from the cleaners) not appearing very happy or overly friendly." 
With $63 \%$ of positive comments, staff and wellness experts had proper Responsiveness and were willing to help and needed little prompting to solve customer issues. There were few negative comments which were due to late food service, unresponsive reception, and sluggish staff. For example:

"There is a beach boy sitting in a hut whose job is obviously to look at his phone all day since he doesn't straighten any beds sweep the mats or pull them straight and make it all look tidy and inviting."

Figure 3 illustrates the importance of each quality dimension. Tangibles have been ranked to be the most influencing factor followed by Empathy, Assurance, Reliability, and Responsiveness as per their importance in customer delivery quality of a wellness resort. The ranking has been done by descending order of the values calculated using TEARR Score, given by the formula:

Weight of each SERVQUAL Dimension $(\boldsymbol{a})=\left(\frac{\text { Total reviews of each dimension }}{\text { Total Reviews of all dimensions }}\right)$

Weight of Negativity of each SERVQUAL Dimension $(\boldsymbol{b})=\left(\frac{\text { Negative Percentage of each Dimension }}{\text { Total Negative Percentage }}\right)$

TEARR Score $(\boldsymbol{c})=($ a $) X(b)$

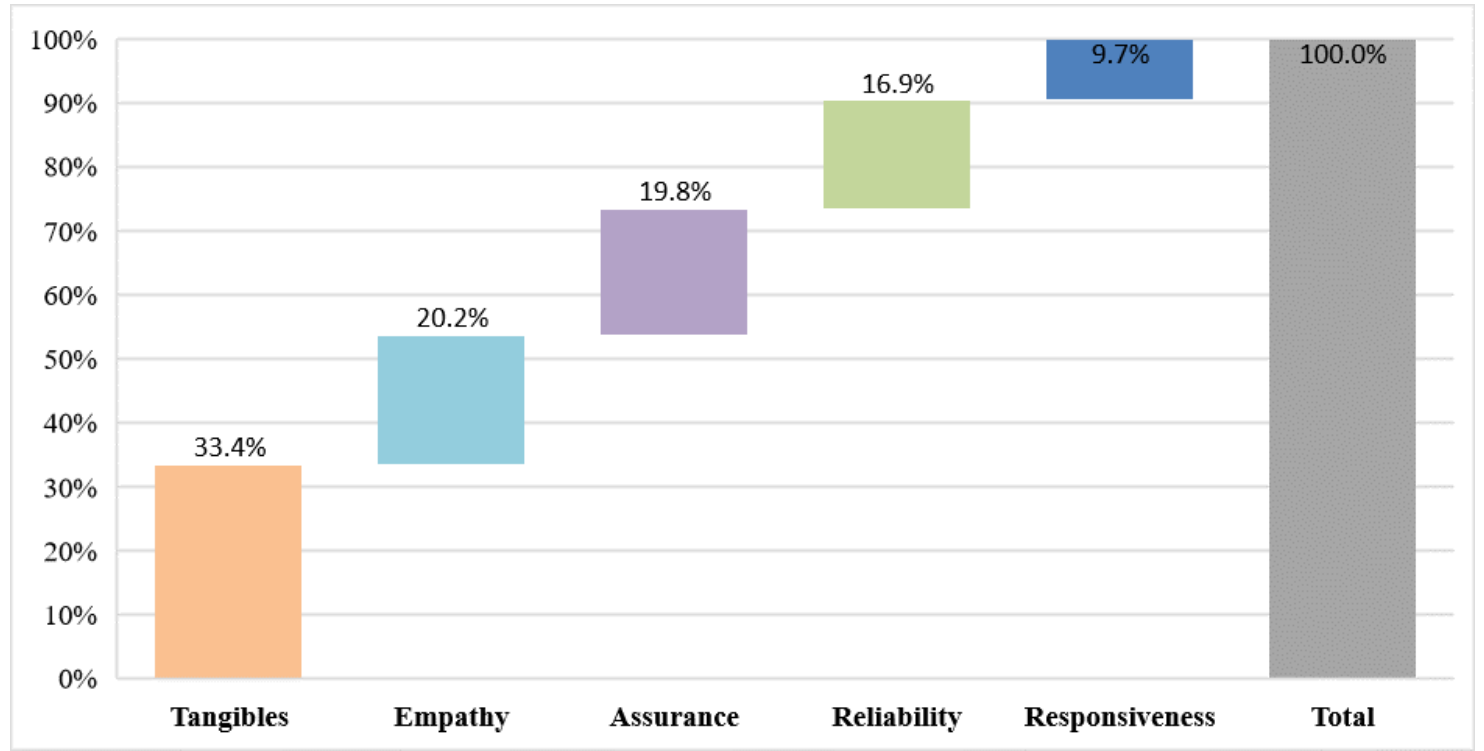

Figure 3. Importance of each dimension as calculated using TEARR Score formula

Table 6 cyberpunk codex shows a detailed analysis of each attribute under each dimension. The sentiment shared for each attribute has been converted to a 5-point Likert scale in which 1 is highly dissatisfied and 5 is 
highly satisfied. The formula implemented for the scale conversion is given by:

Likert Rating $=$

$\underline{\text { (No. of Positive sentences } X 1+\text { No. of Negative sentences } X 0+\text { No.of Neutral sentences } X 0.5)}$

Total sentences

Table 6. Customer satisfaction rating for each attribute in the form of Likert scale

\begin{tabular}{|c|c|c|c|}
\hline $\begin{array}{l}\text { SERVQUAL } \\
\text { Dimensions }\end{array}$ & Code & Attributes & $\begin{array}{l}\text { Likert Scale Rating } \\
\text { (1- Highly Dissatisfied } \\
\text { to 5-Highly Satisfied) }\end{array}$ \\
\hline \multirow{14}{*}{ 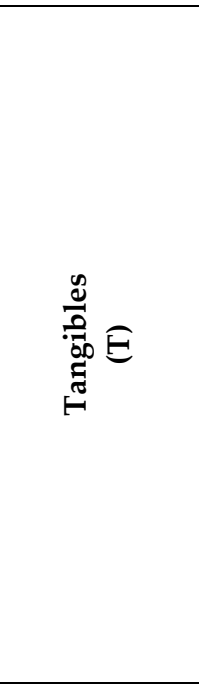 } & $\mathrm{T} 1$ & The resort has excellent modern facilities & $-=1$ \\
\hline & $\mathrm{T} 2$ & The resort has good interior designs & -12 \\
\hline & $\mathrm{T} 3$ & The resort has good exterior designs & $-1,3=4$ \\
\hline & $\mathrm{T} 4$ & The employees are neat and look good & $\begin{array}{lllll}1 & 3 & 4 & 5\end{array}$ \\
\hline & T5 & The resort has a good aesthetic feel & $=\begin{array}{lllll}1 & 2 & 3 & 4 & 1\end{array}$ \\
\hline & T6 & The resort provides good food & $-1,1+1_{4}^{1}$ \\
\hline & $\mathrm{T} 7$ & The resort is kept clean and tidy & $-\ldots !=+$ \\
\hline & $\mathrm{T} 8$ & The resort has good accommodation facility & $\begin{array}{lllll}1 & 2 & 3 & 4 & 5\end{array}$ \\
\hline & T9 & The resort feels safe and secure & $\square_{4}$ \\
\hline & $\mathrm{T} 10$ & The resort room is very good & 45 \\
\hline & $\mathrm{T} 11$ & $\begin{array}{l}\text { The wellness centre has excellent modern } \\
\text { facilities }\end{array}$ & 12 \\
\hline & $\mathrm{T} 12$ & The wellness centre has good aesthetics & $-1=15_{4}$ \\
\hline & & Overall: & 123 \\
\hline & & $-\left.\sum_{1} \int_{3}\right|_{4}$ & \\
\hline \multirow{13}{*}{ 气 } & R1 & Services are obtained in time & $\square_{+}$ \\
\hline & $\mathrm{R} 2$ & The resort staff provides prompt service & -12145 \\
\hline & R3 & Service is done perfectly in the first instance & $\begin{array}{lllllll}1 & 2 & 3 & 4 & 5\end{array}$ \\
\hline & $\mathrm{R} 4$ & Service is delivered without any mistakes & $1:$ \\
\hline & R5 & Staff have good communication skills & 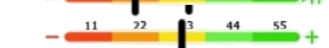 \\
\hline & R6 & Staff are well-knowledgeable & \begin{tabular}{ll|ll}
-1 & 2 & 4 & 5 \\
-1
\end{tabular} \\
\hline & R7 & Staff are well-trained & -12354 \\
\hline & R8 & Staff are well-experienced & 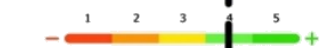 \\
\hline & R9 & Services are provided at a convenient time & $-1 \mathbf{I}^{3} \quad \mathrm{C}_{4}$ \\
\hline & R10 & Staff can fulfil promises & $-1 ! 1=4$ \\
\hline & R11 & Staff have a solving attitude & 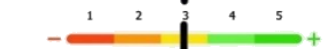 \\
\hline & & Overall: & $1 \quad 2 \quad 3 \quad 4 \quad 5$ \\
\hline & & 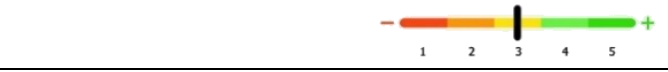 & \\
\hline \multirow{7}{*}{ 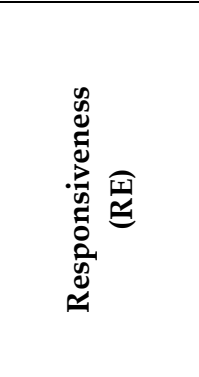 } & RE1 & Staff provides prompt service & $-\underset{1}{-}$ \\
\hline & RE2 & Complaints are quickly resolved & $-\left.12^{2}\right|_{4} ^{5}$ \\
\hline & RE3 & Staff are always willing to help & $\begin{array}{llll}1 & 2 & 3 & 5\end{array}$ \\
\hline & RE4 & Staff are available when required & $-12 \int_{4}=4$ \\
\hline & RE5 & Customer suggestions are well-addressed & 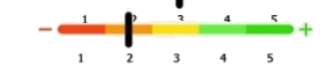 \\
\hline & & Overall: & \\
\hline & & 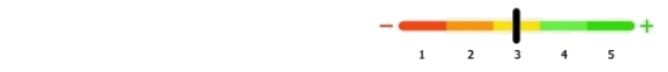 & \\
\hline
\end{tabular}




\begin{tabular}{|c|c|c|c|}
\hline $\begin{array}{l}\text { SERVQUAL } \\
\text { Dimensions }\end{array}$ & Code & Attributes & $\begin{array}{l}\text { Likert Scale Rating } \\
\text { (1- Highly Dissatisfied } \\
\text { to 5-Highly Satisfied) }\end{array}$ \\
\hline \multirow{8}{*}{ 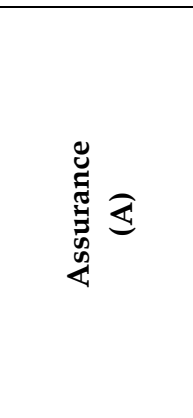 } & A1 & $\begin{array}{l}\text { Customers feel safe with the delivery of } \\
\text { service }\end{array}$ & \\
\hline & $\mathrm{A} 2$ & Practitioners are knowledgeable & $1233^{4} 5$ \\
\hline & A3 & Staff reinforces trust and confidence & $33_{3}^{4}$ \\
\hline & A4 & Staff are polite and courteous & $=1 \ldots$ \\
\hline & A5 & Practitioners are skilled & $-12^{1} x^{3} 5_{4}$ \\
\hline & A6 & Staff behave friendly and sociable & $-1=10_{4}^{1}$ \\
\hline & & Overall: & $123_{4} 5$ \\
\hline & & $-\left.\varlimsup_{12_{2}}\right|_{3{ }_{4}{ }_{5}} 4$ & \\
\hline \multirow{9}{*}{ 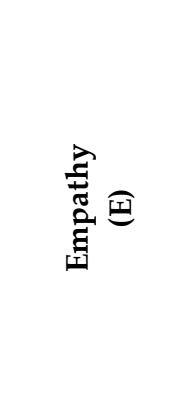 } & E1 & Staff provides individual attention & $=-1$ \\
\hline & E2 & Practitioners provide good care & $-1 !=1=4$ \\
\hline & E3 & Staff understands specific needs & $-1=3 \quad 4 \quad 5$ \\
\hline & $\mathrm{E} 4$ & Staff attains interest in customer needs & $=1-3-5^{-3}$ \\
\hline & E5 & The resort provides loyalty programme & $-1=1=4$ \\
\hline & E6 & Room service is available when required & $-t^{2} \quad 3 \quad 4 \quad 5$ \\
\hline & E7 & Staff patiently listens to complaints & $-i^{2} \mathbf{l}^{4} 5$ \\
\hline & & Overall: & $12 \int_{3} 45$ \\
\hline & & $-\left.\underbrace{}_{1}\right|_{3_{3}{ }_{4}}+$ & \\
\hline
\end{tabular}

\section{DISCUSSION, CONCLUSIONS, AND IMPLICATIONS}

Wellness resorts are innovative and adaptive service providers in the tourism and travel industry. For example, in the context of service quality, many resorts and hotels are providing customer-oriented wellness treatments for meeting the expectations of customers. This study focuses on the importance of service quality, the identification of dimensions and parameters of service quality in Indian wellness resorts.

The results of sentiment analysis are very valuable since they show the importance of being able to quickly and effectively understand customer sentiments from hotel reviews. Wellness tourists in India share different sentiments across different identified dimensions. This helps identify the areas in which the wellness industry can improve to better serve customers. As shown in this study, we were able to gather a large amount of data with good information from the online platforms. This helped us to analyse customer intentions towards wellness resorts in India. The process took less time than a survey and was effective. Questionnaire-based studies are generally closed-ended and restricted, but online reviews help to gain additional information. The findings of this study, which were obtained through text analysis of 400 customer reviews, suggest that the most critical 
service quality dimension is tangibles, followed by empathy, assurance, reliability, and responsiveness.

This study finds the crucial factors which may help to enhance the customer experience in Indian wellness resorts and supports the findings of similar studies. From the present study and analysis, tangibility was concluded to be the most important factor and responsiveness to be the least important. Previous studies have suggested both tangibility and responsiveness be critical as compared to other dimensions (Lewis \& Nightingale, 1991). Our study is in line with those of Choi and Chu (2001) in which they identified staff behaviour, service delivery, quality of accommodation, and overall value to be the most critical factors influencing customer satisfaction and retention. The latter study also concluded that empathy and assurance are deciding factors for gaining customer loyalty, which were ranked the second and third most important factors after tangibility. The present study also finds that staff was least empathetic with customers and slowly progressive in solving their issues. Empathy plays a defending role in the customer and service provider relationship. Presentation of empathetic behaviour by service employees during interpersonal interactions with customers positively affects commitment, perceived quality of service, and satisfaction (Jones \& Shandiz, 2015; Richard et al., 2016). Staff empathetic behaviour is crucial for leveraging trust and loyalty among visitors (Meneses \& Larkin, 2012; Wieseke et al., 2012).

Our paper also develops a Naïve Bayes machine learning model customised for service measurement for wellness resorts in India. This model may be used by marketers and practitioners to understand recent customer reviews and predict and interpret future customer service and concerns. Figure 4 exhibits the rank from the most important factor to the least important on which to focus on developing wellness resort service quality in India. The following formula was developed to rank each attribute of each dimension:

Priority Score $=(5-$ Likert Scale Rating $) *\left(\frac{\text { Total reviews under each attribute }}{\text { Total Reviews }}\right)$

After prioritising each attribute individually with the help of the priority score (the more the magnitude, the more important the factor). It can be interpreted that the four most important attributes that these resorts should focus on are 1) understanding customers' specific needs, 2) improving the room quality and food quality, 3) developing overall 
accommodation facility, and 4) creating trust and confidence among the customers.

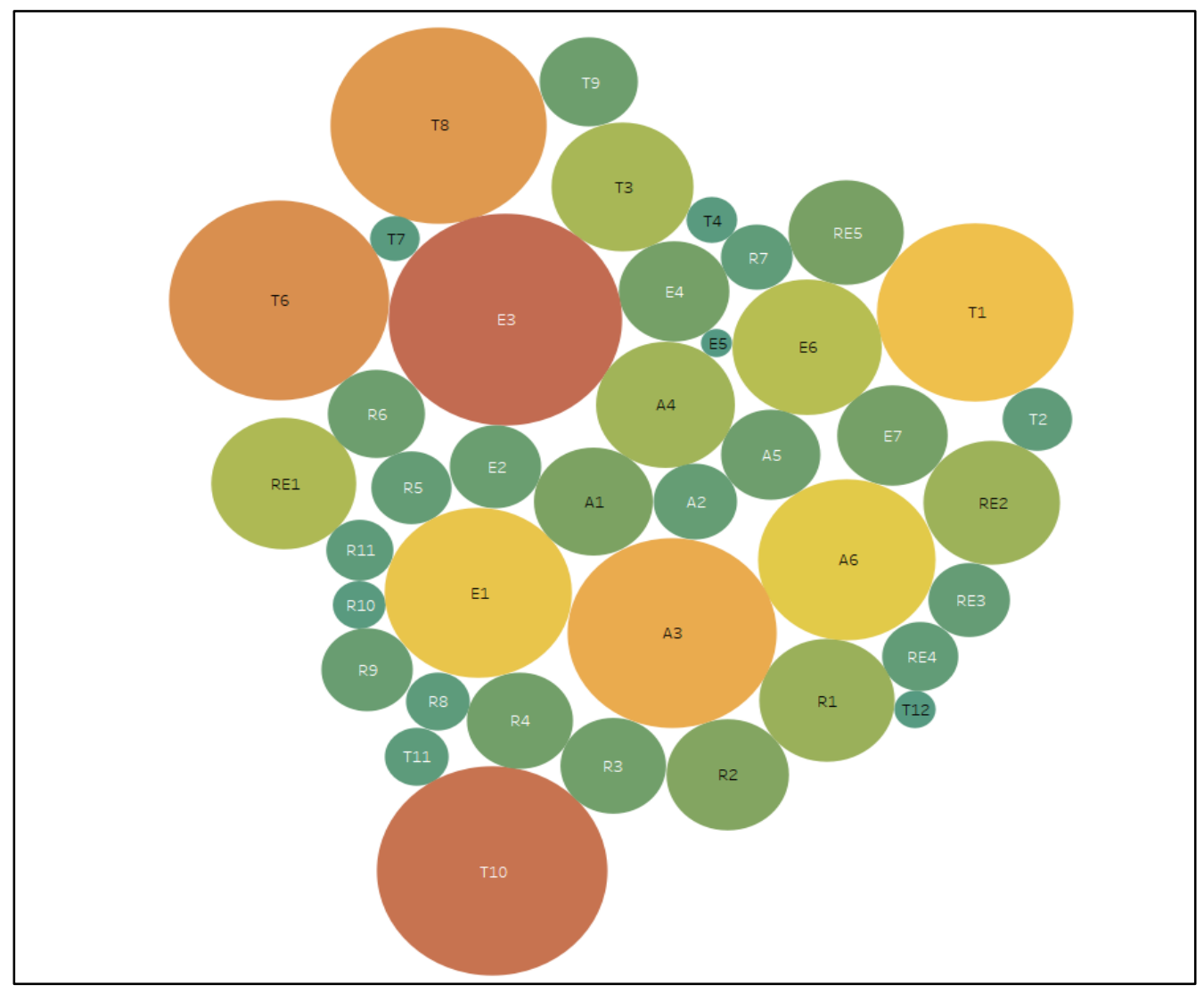

Figure 4. SERVQUAL attributes sorted in order of most important (Biggest Circle) to the least important (Smallest Circle)

Note: T: Tangibles, R: Reliability, RE: Responsiveness, E: Empathy, A: Assurance, for detailed coding see Annex A.

\section{Implications}

For managers and policymakers, this study unravels the knowledge of the potential of social media as a tool to understand the customer experience. One of the most important practical implications of the study is to recommend that hoteliers create proper training methodologies for employees to improve service delivery. From many service dimensions, current study helps Indian wellness resorts to focus on dimensions that need more priority. The suggestions will help to adopt a quality-oriented approach to continually improve the ability to understand the specific needs and expectations of customers.

This study highlights the use of innovate methods and data extraction tools or techniques which help to acquire customer feedbacks 
from social media platform, helping academic and industry researchers in developing online data retrieval process. The machine learning-based methods help for the faster interpretation of customer feedback. This may help marketing managers to decrease the possibilities of negative impact on their brand image by quick response to the problems. Evaluating customer reviews also helps in acquiring new insights as well as prospective customer requirements. This may not be possible in traditional close-ended questionnaire-based approaches. Machine learning approaches predict real-time customer experiences without much manual intervention, thus reducing business costs and valuable time.

\section{Limitations}

Despite the noteworthy academic and managerial achievements from this study, there are few limitations. First, the research was conducted in a restricted timeframe which limited the horizon to find additional issues that customers would have been facing. Second, due to frequent changes in rules and regulations in social media law, it is always a challenge to legitimately access online data. Third, the study only considered the top wellness resorts; this minimises the probability of negative services happening in other wellness resorts existing in India. A broader sample of wellness carerelated resorts may improve the understanding of current wellness service quality in India. In addition, the training set was created manually to get a more accurate result. Manual creation of a dataset may increase the accuracy but adds to the cost and time required. A combination of LEXICON and machine learning-based sentiment analysis approaches may contribute to the advantage by minimising the time and cost involved in these types of methodologies and processes. Alternatively, a machine learning technique other than Naïve Bayes, such as neural networks and different deep learning algorithms, may improve model accuracy.

\section{Conclusions}

The paper contributes to the existing literature on wellness care service facilities. With the growth in technological know-how and social media content, this study helps to understand how technology-based research may help wellness care centres/resorts and similar service providers in the tourism industry. This study showcases a more cost-effective and robust methodology in gaining accurate customer insights. A machine learningbased sentiment analysis approach for evaluating customer experience may help organisations understand tourist needs and issues from information that already exists on social media in an unstructured format. Furthermore, 
this paper contributes to the theoretical level by introducing machine learning, opinion mining, and text analytics into the field of management studies. This study also contributes to the existing literature on the SERVQUAL model. Ordinary facilities, poor food quality, unmaintained amenities, late service and delayed response to complaints, improper training, and sluggish behaviour are the real issues behind negative sentiments. At an overall level, the empathetic behaviour of hotel staff was not up to the mark. On the positive side, customers were satisfied with the wellness care service provided by practitioners. The findings were supported by some studies (Meneses \& Larkin, 2012; Wieseke et al., 2012) while they deviated from others (Voss et al., 2004). The main reason for the variance in findings on customer perceptions is due to different geography and cultural differences. Prior research on culture indicates that customer behaviour is not necessarily constant across countries. Culture is essential to service management because customer behaviour is affected by the environment, including national culture (Roth, 1995). Service quality is defined by the extent of the gap between customer expectations for and perceptions of the service (Zeithaml et al., 1990). Customer sentiment was examined as the basis of the measurement of the gap between expectations and perceptions. Moreover, the present research uncovered additional reasons behind negative sentiments.

\section{REFERENCES}

Alaei, A. R., Becken, S., \& Stantic, B. (2019). Sentiment analysis in tourism: Capitalizing on big data. Journal of Travel Research, 58(2), 175-191.

Ali-Knight, J. (2009). Yoga tourism. In R. Bushell \& P. J. Sheldon (Eds.), Wellness and Tourism: Mind, Body, Spirit, Place (pp. 84-95). New York, NY: Cognizant Communication Corporation.

Arasli, H., Mehtap-Smadi, S., \& Katircioglu, S. T. (2005). Customer service quality in the Greek Cypriot banking industry. Managing Service Quality: An International Journal, 15(1), 41-56.

Arnold, S. (2011). From sentiment to applications. KM World, 20(7), 1-20.

Bhat, M. A. (2012). Tourism service quality: A dimension-specific assessment of SERVQUAL. Global Business Review, 13(2), 327-337.

Bhowmick, T. (2018). An overview of Medical and Wellness Tourism in India. IOSR Journal of Business and Management, 2, 68-72.

Blackshaw, T. (2005). Zygmunt Bauman. Abington: Routledge.

Boyd, D., \& Ellison, N. (2007). Social network sites: Definition, history, and scholarship. Journal of Computer-Mediated Communication, 13(1), 56-62.

Choi, T. Y., \& Chu, R. (2001). Determinants of hotel guests' satisfaction and repeat patronage in the Hong Kong hotel industry. International Journal of Hospitality Management, 20(3), 277-297. 
Cohen, J. (1960). A coefficient of agreement for nominal scales. Educational and psychological measurement, 20(1), 37-46.

Constantinides, E., \& Fountain, S. (2008). Web 2.0: Conceptual foundations and marketing issues. Journal of Direct, Data and Digital Marketing Practice, 9(3), 231-244.

Cronin Jr, J. J., \& Taylor, S. A. (1992). Measuring service quality: a reexamination and extension. Journal of marketing, 56(3), 55-68.

Csirmaz, É., \& Pető, K. (2015). International trends in recreational and wellness tourism. Procedia economics and finance, 32, 755-762.

Deshpande, M., \& Sarkar, A. (2010). BI and sentiment analysis. Business Intelligence Journal, 15(2), 41-50.

Douglas, N. (2001). Travelling for health: Spa and health resorts. In N. Douglas \& R. Derrett (Eds.), Special Interest Tourism: Context and Cases (pp. 260-282). Hoboken, NJ: Wiley.

Geho, P., Smith, S., \& Lewis, S. (2010). Is Twitter a viable commercial use platform for small businesses? An empirical study targeting two audiences in the small business community. The Entrepreneurial Executive, 15(1), 73-85.

Global Wellness Institute (2017). Global wellness economy monitor. Retrieved 19 December, 2019, from https://globalwellnessinstitute.org/wpcontent/uploads/2018/06/GWI_WellnessEconomyMonitor2017_FINALweb.pdf

Global Wellness Institute (2018). Global wellness economy monitor. Retrieved 19 December, 2019, from https://globalwellnessinstitute.org/wpcontent/uploads/2018/10/Research2018_v5FINALExecutiveSummary_webREVIS ED.pdf

Global Wellness Institute (2019). Global wellness economy bubble chart. Retrieved 19 December, 2019, from https://globalwellnessinstitute.org/wpcontent/uploads/2019/12/Global-Wellness-Economy-Bubble-Chart-2019.pdf

Godolja, M., \& Spaho, A. (2014). Customer satisfaction measurement practices in hotels: Some evidence from Albania. In 10th International Conference of ASECU, Cluj Napoca, Romania. Retrieved 04 July, 2019, from http://www. asecu. gr/files/10th_conf_files/godolja-spaho.pdf

Gretzel, U., \& Yoo, K. H. (2008). Use and impact of online travel reviews. In P. O'Connor, W. Höpken, \& U. Gretzel (Eds.), Information and Communication Technologies in Tourism. New York, NY: Springer.

Hall, C. M. (1992). Adventure, sport and health tourism. In B. Weiler \& C. M. Hall (Eds.), Special Interest Tourism (pp. 141-158). London: Belhaven Press.

Hall, C. M., Voigt, C., Brown, G., \& Howat, G. (2011). Wellness tourists: In search of transformation. Tourism Review, 66(1-2), 16-30.

Hutchinson, J., Lai, F., \& Wang, Y. (2009). Understanding the relationships of quality, value, equity, satisfaction, and behavioral intentions among golf travelers. Tourism Management, 30(2), 298-308.

Jones, J. L., \& Shandiz, M. (2015). Service quality expectations: Exploring the importance of SERVQUAL dimensions from different nonprofit constituent groups. Journal of Nonprofit \& Public Sector Marketing, 27(1), 48-69.

Joshi, R. (2016). Accuracy, Precision, Recall \& F1 Score: Interpretation of Performance Measures. Retrieved 17 July, 2019, from https://blog.exsilio.com/all/accuracyprecision-recall-f1-score-interpretation-of-performance-measures/

Juwaheer, T. D. (2004). Exploring international tourists' perceptions of hotel operations by using a modified SERVQUAL approach - a case study of Mauritius. Managing Service Quality, 14(5), 350 - 364 
Karai, V. K. (2019). What will 2019 bring for wellness tourism in India: An outlook. Entrepreneur. Retrieved 19 September, 2019, from https://www.entrepreneur.com/article/325229

Kho, N. D. (2010). Customer experience and sentiment analysis. KM World, 19(2), 10-20.

Koppel, M., \& Schler, J. (2006). The importance of neutral examples for learning sentiment. Computational Intelligence, 22(2), 100-109.

Ku, L., Huang, T., \& Chen, H. (2009). Using morphological and syntactic structures for Chinese opinion analysis. In Proceedings of EMNLP 2009, pp. 1260-1269.

Kulczycki, C., \& Luck, M. (2009). Outdoor adventure tourism, wellness, and place attachment. In R. Bushell \& P.J. Sheldon (Eds.), Wellness and Tourism: Mind, Body, Spirit, Place (pp. 165-76). New York, NY: Cognizant Communication Corporation.

Lean, G. L. (2009). Transformative travel: Inspiring sustainability. In R. Bushell \& P.J. Sheldon (Eds.), Wellness and tourism: Mind, body, spirit, place (191-205). New York, NY: Cognizant Communication Corporation.

Lewis, R. C., \& Nightingale, M. (1991). Targeting service to your consumer. Cornell Hotel and Restaurant Administration Quarterly, 32(2), 18-27.

Markovic, S., Raspor, S., \& Komšic, J. (2012). Service quality measurement in Croatian wellness tourism: An application of the SERVQUAL scale. Academica TuristicaTourism and Innovation Journal, 5(1), 47-58.

Marshall, A. (1993). Safety top guest's priority list: Sell security as No.1 amenity. Hotel and Motel Management, 208(11), 21.

Meneses, R. W., \& Larkin, M. (2012). Edith Stein and the contemporary psychological study of empathy. Journal of Phenomenological Psychology, 43(2), 151-184.

Ministry of Tourism, Government of India (2020). India Tourism Statistics at a Glance - 2020. Ministry of Tourism, Government of India. Retrieved 15 January, 2021 from https://tourism.gov.in/sites/default/files/2020-

09/ITS\%20at $\% 20$ a $\% 20$ glance_Book $\% 20 \% 282 \% 29$.pdf.

Ministry of Tourism, Government of India (2019). India Tourism 2019. Ministry of Tourism Government of India. Retrieved 15 January, 2021 from https://tourism.gov.in/sites/default/files/2020-

04/India\%20Tourism\%20Statistics\%202019.pdf.

Misopoulos, F., Mitic, M., Kapoulas, A., \& Karapiperis, C. (2014). Uncovering customer service experiences with Twitter: The case of airline industry. Management Decision, 52(4), 705-723.

Muturi, D., Sagwe, J., \& Namukasa, J. (2013). The influence of airline service quality on passenger satisfaction and loyalty. The TQM journal, 25(5), 520-532.

Neto, F. (2003, August). A new approach to sustainable tourism development: Moving beyond environmental protection. In Natural resources forum, 27(3), 212-222. Oxford, UK: Blackwell Publishing Ltd.

Oberoi, U., \& Hales, C. (1990). Assessing the quality of the conference hotel service product: Towards an empirically based model. Service Industries Journal, 10(4), 700-721.

O'Leary, D. (2011). The use of social media in the supply chain: Survey and extensions. Intelligent Systems in Accounting, Finance and Management, 18(2/3), 121-144.

Parasuraman, A., Berry, L.L., \& Zeithaml, V.A. (1991). Refinement and reassessment of the SERVQUAL scale. Journal of retailing, 67(4), 420-450.

Parasuraman, A., Zeithaml, V., \& Berry, L. (1985). A conceptual model of service quality and its implications for future research. Journal of Marketing, 49(4), 41-50. 
Parasuraman, A., Zeithaml, V.A., \& Berry, L.L. (1988). SERVQUAL: A multiple-item scale for measuring consumer perceptions of service quality. Journal of retailing, 64(1), $12-40$.

Peng, F., \& Schuurmans, D. (2003). Combining Naive Bayes and n-Gram Language Models for text classification. In F. Sebastiani (Ed.), Advances in Information Retrieval, (pp. 335-350). Springer, Berlin, Heidelberg. https://doi.org/10.1007/3-540-36618-0_24

Philander, K., \& Zhong, Y. (2016). Twitter sentiment analysis: Capturing sentiment from integrated resort tweets. International Journal of Hospitality Management, 55(1), 1624.

Pollock, A., \& Williams, P. (2000). Health tourism trends: Closing the gap between health care and tourism. In W.C. Gartner \& D.W. Lime (Eds.), Trends in Outdoor Recreation, Leisure and Tourism (pp. 165-173). Wallingford: Cabi Publishing

Rai, M. (2018). The best wellness retreats in India. Retrieved 24 December, 2018, from https://theculturetrip.com/asia/india/articles/the-best-wellness-retreats-in-india/

Rambocas, M., \& Pacheco, B. G. (2018). Online sentiment analysis in marketing research: A review. Journal of Research in Interactive Marketing, 12(2), 146-163.

Ramsaran-Fowdar, R. R. (2007). Developing a service quality questionnaire for the hotel industry in Mauritius. Journal of Vacation Marketing, 13(1), 19-27.

Richard, E. M., Bupp, C. P., \& Alzaidalsharief, R. G. (2016). Supervisor empathy moderates the negative effects of customer injustice. Emotions and Organizational Governance, $12,117-140$.

Roth, M. S. (1995). The effects of culture and socioeconomics on the performance of global brand image strategies. Journal of Marketing Research, 32(2), 163-175.

Santos, J. (2003). E-service quality: a model of virtual service quality dimensions. Managing Service Quality: An International Journal, 13(3), 233-246.

Shahin, A., \& Chan, J.F.L. (2006). Customer requirements segmentation (CRS): A prerequisite technique for quality function deployment (QFD). Total Quality Management \& Business Excellence, 17(5), 567-587.

Sharma, C. (2014). A service quality model applied on indian hotel industry to measure the level of customer satisfaction. International Journal of Scientific Research, 3(3), 480485.

Singh, B. J., \& Khanduja, D. (2010). SMED: for quick changeovers in foundry SMEs. International Journal of Productivity and Performance Management, 59(1), 98-116.

Smith, M., \& Kelly, C. (2006). Holistic tourism: Journeys of the self?. Tourism Recreation Research, 31(1), 15-24.

Smith, M., \& Puczko', L. (2008). Health and wellness tourism. Routledge.

Sointu, E. (2006). The search for wellbeing in alternative and complementary health practices. Sociology of Health \& Illness, 28(3), 330-49.

Thelwall, M., Buckely, E., \& Paltoglou, G. (2011). Sentiment in Twitter events. Journal of the American Society for Information Science and Technology, 62(2), 406-418.

Voss, C. A., Roth, A. V., Rosenzweig, E. D., Blackmon, K., \& Chase, R. B. (2004). A tale of two countries' conservatism, service quality, and feedback on customer satisfaction. Journal of Service Research, 6(3), 212-230.

Wei, C. P., Chen, Y. M., Yang, C. S., \& Yang, C. (2008). Understanding what concerns consumers: A semantic approach to product feature extraction from consumer reviews. Information Systems and e-Business Management, 8, 149-167.

Weiermair, K., \& Steinhauser, C. (2003). New tourism clusters in the field of sports and health: The case of Alpine Wellness. In the preoceedings of 12th International Tourism and Leisure Symposium (15-18), Barcelona. 
Wieseke, J., Geigenmüller, A., \& Kraus, F. (2012). On the role of empathy in customeremployee interactions. Journal of Service Research, 15(3), 316-331.

Xiang, Z., Tussyadiah, I., \& Buhalis, D. (2015). Smart destinations: Foundations, analytics, and applications. Journal of Destination Marketing and Management, 4(3), 143-144.

Yang, Y., Mao, Z., \& Tang, J. (2018). Understanding guest satisfaction with urban hotel location. Journal of Travel Research, 57(2), 243-259.

Ye, Q., Zhang, Z., \& Law, R. (2009). Sentiment classification of online reviews to travel destinations by supervised machine learning approaches. Expert systems with applications, 36(3), 6527-6535.

Zeithaml, V. A., Berry, L. L., \& Parasuraman, A. (1996). The behavioral consequences of service quality. Journal of marketing, 60(2), 31-46.

Zeithaml, V. A., Parasuraman, A., Berry, L. L., \& Berry, L. L. (1990). Delivering quality service: Balancing customer perceptions and expectations. New York: Simon and Schuster.

\section{APPENDIX}

Annex A. The SERVQUAL dimensions and attributes used in our study

\begin{tabular}{|c|c|c|}
\hline SERVQUAL Dimensions & Code & Attributes \\
\hline \multirow{12}{*}{ 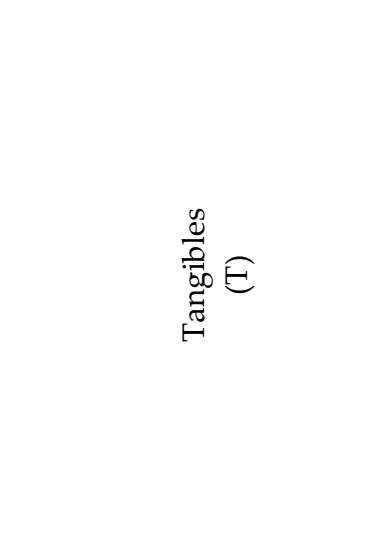 } & $\mathrm{T} 1$ & The resort has excellent modern facilities \\
\hline & $\mathrm{T} 2$ & The resort has good interior designs \\
\hline & T3 & The resort has good exterior designs \\
\hline & $\mathrm{T} 4$ & The employees are neat and look good \\
\hline & T5 & The resort has a good aesthetic feel \\
\hline & T6 & The resort provides good food \\
\hline & $\mathrm{T} 7$ & The resort is kept clean and tidy \\
\hline & $\mathrm{T} 8$ & The resort has good accommodation facility \\
\hline & T9 & The resort feels safe and secure \\
\hline & $\mathrm{T} 10$ & The resort room is perfect \\
\hline & $\mathrm{T} 11$ & The wellness centre has excellent modern facilities \\
\hline & $\mathrm{T} 12$ & The wellness centre has good aesthetics \\
\hline \multirow{11}{*}{ 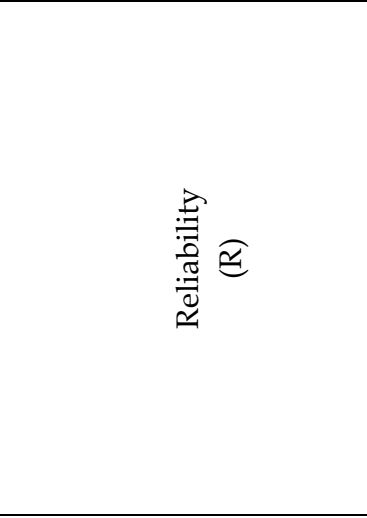 } & R1 & Services are obtained in time \\
\hline & $\mathrm{R} 2$ & The resort staff provides prompt service \\
\hline & R3 & Service is done perfectly in the first instance \\
\hline & $\mathrm{R} 4$ & Service is delivered without any mistakes \\
\hline & R5 & Staff have good communication skills \\
\hline & R6 & Staff are well-knowledgeable \\
\hline & R7 & Staff are well-trained \\
\hline & R8 & Staff are well-experienced \\
\hline & R9 & Services are provided at a convenient time \\
\hline & R10 & Staff can fulfil promises \\
\hline & $\mathrm{R} 11$ & Staff have a solving attitude \\
\hline \multirow{5}{*}{ 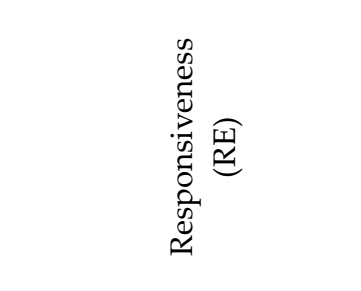 } & RE1 & Staff provide prompt service \\
\hline & RE2 & Complaints are quickly resolved \\
\hline & RE3 & Staff are always willing to help \\
\hline & RE4 & Staff are available when required \\
\hline & RE5 & Customer suggestions are well-addressed \\
\hline
\end{tabular}




\begin{tabular}{lll}
\hline & A1 & Customers feel safe with the delivery of service \\
A2 & Practitioners are knowledgeable \\
A3 & Staff reinforces trust and confidence \\
A4 & Staff are polite and courteous \\
A5 & Practitioners are skilled \\
A6 & Staff behave friendly and sociable \\
\hline E1 & Staff provides individual attention \\
E2 & Practitioners provide good care \\
E3 & Staff understands specific needs \\
E4 & Staff attains interest in customer needs \\
E5 & The resort provides loyalty programmes \\
E6 & Room service is available when required \\
E7 & Staff patiently listens to complaints \\
\hline
\end{tabular}

Annex B. Formulas used to calculate different elements in confusion matrix

\begin{tabular}{|c|c|c|}
\hline Particulars & & Formula \\
\hline \multirow[t]{2}{*}{ F1 Score } & \multirow{2}{*}{$=$} & \multirow{2}{*}{$2 \times \frac{(\text { Sensitivity } \times \text { Precision })}{(\text { Sensitivity }+ \text { Precision })}$} \\
\hline & & \\
\hline \multirow[t]{2}{*}{ Accuracy } & \multirow{2}{*}{$=$} & Number of correct predictions \\
\hline & & Total number of predictions \\
\hline \multirow{4}{*}{ Cohen's Kappa } & \multicolumn{2}{|r|}{$P_{o b s}+P_{\text {chance }}$} \\
\hline & & $\overline{1-P_{\text {chance }}}$ \\
\hline & & $P_{\text {obs }}=$ Probability of relative observed agreement \\
\hline & $=$ & $P_{\text {chance }}=$ Probability of agreement based on chance \\
\hline \multirow{2}{*}{ Sensitivity } & \multirow[b]{2}{*}{$=$} & Total True Positives \\
\hline & & $\overline{\text { Total True Positives + Total False Negatives }}$ \\
\hline \multirow{2}{*}{ Specificity } & \multirow[b]{2}{*}{$=$} & Total True Negatives \\
\hline & & $\overline{\text { Total True Negatives }+ \text { Total False Positives }}$ \\
\hline \multirow{2}{*}{ Prevalence } & \multirow{2}{*}{$=$} & Total False Negatives + Total True Positives \\
\hline & & Total Observations \\
\hline \multirow{2}{*}{$\begin{array}{l}\text { Precision Value/ Positive } \\
\text { Predicted Value }\end{array}$} & \multirow{2}{*}{$=$} & Total True Positives \\
\hline & & $\overline{\text { Total True Positives }+ \text { Total False Positives }}$ \\
\hline \multirow{2}{*}{ Negative Predicted Value } & \multirow{2}{*}{$=$} & Total True Negatives \\
\hline & & $\overline{\text { Total True Negatives }+ \text { Total False Negatives }}$ \\
\hline
\end{tabular}

